\title{
Water column and recent sediment data on diatoms and coccolithophorids, off Portugal, confirm sediment record of upwelling events
}

\author{
Fatima ABRANTES ${ }^{a}$, Maria Teresa MOITA ${ }^{\text {b }}$ \\ ${ }^{a}$ GM-DGM - Instituto Geológico e Mineiro, Departamento de Geologia Marinha, Estrada da Portela, Zambujal, 2720 \\ Alfragide, Portugal \\ ${ }^{\mathrm{b}}$ IPIMAR - Instituto Português das Pescas e do Mar, Av. Brasília 1400 Lisboa, Portugal
}

(Received 7 January 1997, revised 6 October 1997, accepted 22 October 1997)

\begin{abstract}
Diatom and coccolithophorid abundance and diatom assemblage composition found in the water column along the Portuguese margin, during upwelling and non-upwelling conditions, are compared to the distribution patterns observed in the recent sediments from the same area. The water column results indicate a one order of magnitude increase in phytoplankton biomass during upwelling conditions (summer), with diatoms being the most important contributors. Coccolithophorids, on the contrary, dominate the phytoplankton in winter (non-upwelling). The comparison of the upwelling and non-upwelling spatial distribution of these phytoplankton groups to their sedimentary record reveals the sediment record as a reflection of the upwelling situation, preserving most of its original spatial variability. The comparison between living and fossil diatom assemblages indicates that from the two genera which dominate the summer biological assemblage, Pseudo-nitzschia and Chaetoceros, Pseudo-nitzschia is not represented in the sediments, while Chaetoceros is the dominant form of the sediment. Thalassiosira, which occurs in the same abundance in both seasons, responding to both river and upwelling nutrient input, can not be a reliable indicator of any single process. However, this genus distribution in the sediments can be used as an indicator of continuous nutrient availability. Such results are of great importance for paleoceanographic reconstructions, since they constitute a good indication that the sediment record, even though somewhat altered with respect to assemblage composition, does reflect the water column characteristics. $\odot$ Elsevier, Paris / Ifremer / Cnrs / Ird
\end{abstract}

\section{upwelling / Portugal / diatom / water column / sediment}

Résumé - Diatomées et coccolithophoridés dans la colonne d'eau et le sédiment et mémoire des upwellings au large du Portugal. L'abondance de diatomées et des coccolithophoridés et la composition des populations de diatomées ont été observées le long de la côte du Portugal dans la colonne d'eau et dans les sédiments récents. Pendant l'upwelling (été), la biomasse du phytoplancton dans la colonne d'eau augmente d'un ordre de grandeur avec les diatomées. En l'absence d'upwelling (hiver), les coccolithophoridés prédominent. La répartition de ces groupes dans le sédiment reflète la situation d'upwelling en conservant la variabilité spatiale originelle. La comparaison entre les populations de diatomées vivantes et les fossiles indique que l'un des deux genres dominants en été, Pseudo-nitzschia, n'est pas représenté dans le sédiment tandis que l'autre, Chaetoceros, y prédomine. Le genre Thalassiosira, présent avec la même abondance pendant les deux saisons, en raison de l'apport de nutriments par le fleuve et par l'upwelling, ne peut être l'indicateur fiable d'un processus unique, mais la présence de ce genre dans les sédiments indique la disponibilité permanente de nutriments. Ces résultats sont d'une grande importance en paléo-océanographie car ils montrent que le sédiment reflète les caractéristiques de la colonne d'eau, malgré les modifications observées dans la composition des populations. (O) Elsevier, Paris / Ifremer / Cnrs / Ird

upwelling / Portugal / diatomée / colonne d'eau / sédiment 


\section{INTRODUCTION}

Reconstruction of the past productivity in the oceans has always been one of the most important issues for paleoceanographers, but since the discovery of a one-third decrease of the atmospheric $\mathrm{CO}_{2}$ during the last glacial age [3] this theme has become a dominant one; given that oceanic productivity is a possible control on long-term changes in atmospheric carbon dioxide concentration.

In today's oceans, $50 \%$ of oceanic productivity is estimated to be concentrated in $30 \%$ of the oceanic area, in margins characterized by the occurrence of coastal upwelling [4]. The observed uncoupling between the primary and secondary producers that occurs in such areas results in significant export flux to the sediments [13]. So, these high sedimentation areas may preserve a great deal of information relative to the past productivity conditions. However, to estimate what biological and chemical characteristics determine the sediment record, we first need to try to relate the sediment record to modern conditions. Difficulties arise from the fact that the species generally preserved in the sediments may not be the ones that dominate the living community. Trap studies reveal a direct relation between the biogenic flux and productivity variations; however, the same type of data also shows that only a small fraction of the exported flux reaches the bottom, and confirms that different biogenic groups have different probabilities of becoming incorporated in the sediments $[7,14,24,28]$.

Even though a great amount of important information, obtained from trap studies, indicates maximum total organic carbon and biogenic opal, with diatoms being the main contributor to these opal fractions, occurring in association with upwelling conditions, $[24,28]$ that information is precise. A better understanding of the relations that exist between the sediment record and the water column processes may also be reached by the comparison of spatial and temporal plankton distributions on the water column to the spatial distribution of the same plankton groups in the surface sediments of several upwelling areas. Such a comparison has, to our knowledge, never been attempted before, but it is, in this paper, made for the Portuguese margin/upwelling system. Absolute diatom abundance patterns found in the surface sediments collected along this margin [1], which is characterized by the occurrence of seasonal upwelling, reflect the actual patterns of upwelling described for the area by Fiúza $[9$, $10]$ and revealed by the pigment content distribution during upwelling events [27]. Diatom assemblages were also used by Abrantes [1] to describe the relationship between the hydrography and the diatom species and groups preserved in surface sediments off Portugal. According to this author, small species of the genus Thalassiosira characterize areas of persistent upwelling where availability of nutrients is more constant and/or higher; Paralia sulcata (Ehr.) Cleve appears as an abundant species with mean cell diameter increasing as nutrient availability decreases and the resting spores of Chaetoceros Ehrenberg, record the position of the inner upwelling front. More recently, Moita [17] presented integrated diatom data (abundance and assemblages composition) for the top $100 \mathrm{~m}$ of the water column for upwelling conditions. Her results show distribution and abundance patterns for diatoms, mostly represented by Pseudo-nitzschia, Chaetoceros and Thalassiosira, reflecting the direct area of influence of the newly upwelled waters.

Diatoms are abundant in the sediments along the Portuguese margin, but the biogenic component of these sediments is very rich in coccolithophorids. These phytoplankton, which are important bloom formers in low productive warm waters, are however, also consistent components of upwelling communities [28]. Off Portugal coccolithophorids mark the southern coast nutrient enriched summer upwelling waters [17].

In this study, we compare two of the published data sets $[1,17]$, with new water column data now available for a non-upwelling situation in order to introduce the possible effect of season into the sediment record as well as to define and/or check the validity of diatom taxa preserved in the sediments as indicators of paleoconditions. Another of the purposes of this paper is to evaluate the importance of coccolithophorids during upwelling versus non-upwelling conditions, as well as in the sediments.

\section{MATERIAL AND METHODS}

Water column sampling was performed off the Portuguese coast, along sixteen to eighteen sections perpendicular to the bathymetry, and up to the $1000 \mathrm{~m}$ isobath, during IPIMAR cruises CICLOS I and CICLOS III. These cruises were made aboard R.V. Noruega, from 20 August to 3 September 1985 and 20 January to 6 February 1986, respectively (figures $1 a, b$ ).

Salinity and temperature were determined at each station for the following depths: $0,5,10,20,30,40,50,75,100$, $125,150,200$ and $300 \mathrm{~m}$ (or near bottom in shallow areas). Samples for phytoplankton analysis and chloro- 
UPWELLING

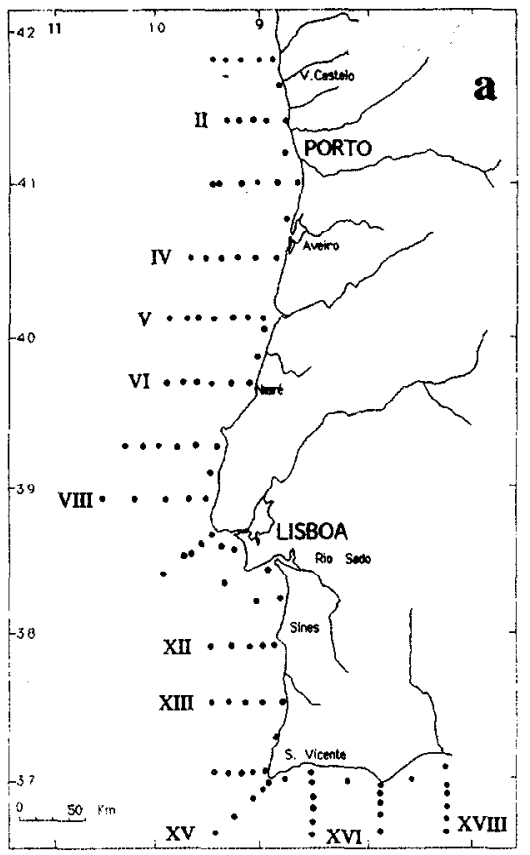

NON-UPWELLING

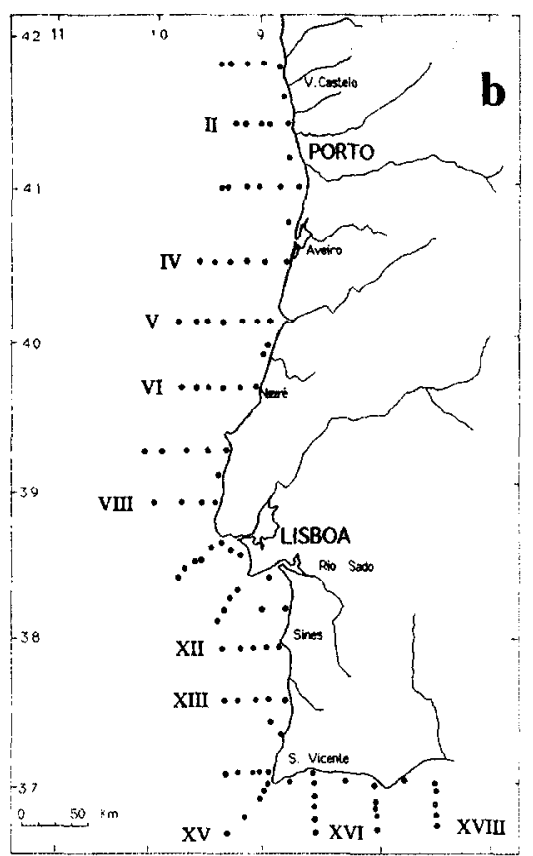

\section{SEDIMENTS}

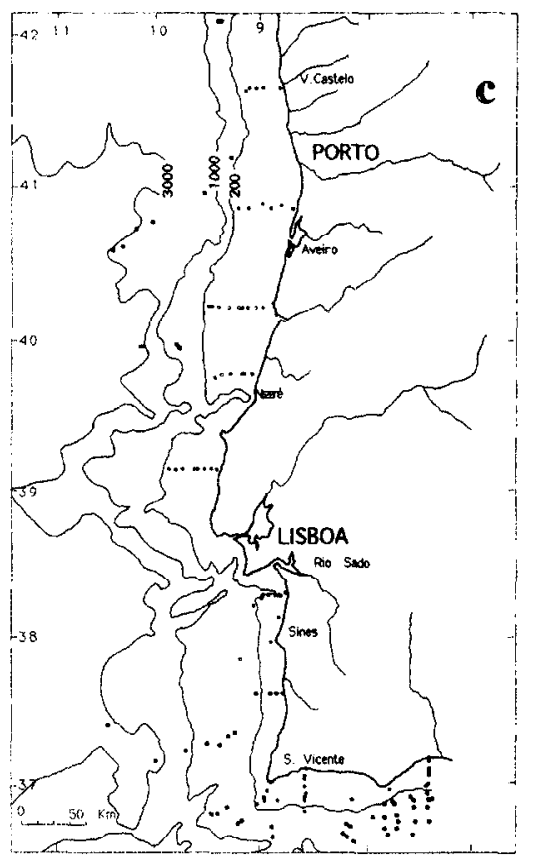

Figure 1. Sample location in relation to regional geographic features. a- Water column summer cruise of August 1985 - CICLOS I; b- Water column winter cruise of January 1986 - CICLOS III; c- Sediment samples: small circles - surficial samples; larger circles - Faegas IV core-tops.

phyll $a$ determinations were collected at the same discrete levels down to $100 \mathrm{~m}$. Temperature was determined from reversing thermometers coupled to Nansen bottles, and salinity (conductivity) was determined using a salinometer BECKMAN Mod. RS7-C. Phytoplankton samples were preserved with hexamethylenetetramine buffered formalin to a final concentration of $2 \%$ and counted under an inverted microscope, with phase contrast and brightfield illumination, using $100 \mathrm{~mL}$ composite settling chambers. Samples from each depth were integrated into one sample per station representing the water column (water samples from each depth were mixed in proportion to the extent of water column that they represented). Chlorophyll $a$ was measured by fluorometry (Perkin-Elmer Mod. 204-A), after extraction in $90 \%$ acetone.

The sediment samples were collected during cruises AC75/1, AC76/1 and AC77/2, conducted by the Department of Marine Geology of the Geological Survey of Portugal aboard R.V. Almeida Carvalho. Surficial shelf sediments were collected with a large Van Veen grab and the slope samples are core-top samples from piston cores collected in October 1982 (Faegas IV - Marine Geology
Group of the University of Bordeaux) (figure 1c). Procedures for the treatment of raw material, preparation of slides, diatom quantitative analysis and definition of counting units are described in Abrantes [2]. Specimens were identified and counted generally to the species level, and its abundance calculated as a percentage of total diatom assemblage.

Coccolithophorid abundance was determined in the $<20 \mu \mathrm{m}$ sediment fraction, by evaluation of the percentage area of a smear-slide occupied by the group.

When defining the diatom assemblages, the genera Chaetoceros and Thalassiosira were treated as groups, even though species were counted separately as much as possible. Chaetoceros species are grouped because their presence in the sediments is mainly in the form of resting spores, most of which cannot be assigned to the vegetative form which generated them. On the other hand, Thalassiosira species are grouped due to the difficulty of properly identifying of the smaller specimens $(<12 \mu \mathrm{m})$ present in the water column using the inverted microscope. 


\section{HYDROGRAPHY}

Upwelling takes place along the west coast of Portugal from April to September under the fairly strong and steady northerly "Portuguese trades" $[9,10,11]$. Based on the analysis of a series of thermal infrared images, Fiúza [9] considers the existence of three main areas, which are characterized by different upwelling patterns. In this respect the west coast, the area north of Nazaré is characterized by an homogenous upwelling along the shore. From Lisbon to Cape Sines, the upwelling structure is complicated both by the presence of coastal protrusions and the Lisbon and Setúbal Canyon. South of Cape Sines, the upwelling structure becomes more regular again, but the shelf water is strongly affected by the warmer and saltier offshore surface waters. On the Algarve coast, upwelling only takes place occasionally when westerly winds occur, but the west Algarve margin gets covered by western upwelled waters carried around Cape St. Vincent, along the shelf break, during upwelling events. This coastal upwelling brings to the surface waters which have slightly different characteristics from south to north, suggesting different sources $[9,10,22]$.
According to Fiuza $[10]$ the upwelling source water is the Eastern North Atlantic Central Water (ENACW), a sub. surface water mass generally present below $100 \mathrm{~m}$ and composed of two branches of different origin and thermohaline characteristics. Rios et al. [22] designated these two branches by Subtropical Eastern North Atlantic Water (ENAWt; ot $<27-27.1$ ) and Subpolar Eastern North Atlantic Water (ENAWp: $27.1<\sigma_{1}<27.3$ ), and consider that ENAWt overlays ENAWp. South of the Nazaré Canyon ENAWt is the upwelling source water, but decreases in importance towards the north where, depending on the wind strength, both branches can be upwelled.

In this paper, cruises CICLOS I (summer) and CICLOS III (winter) are considered to represent an upwelling and a non-upwelling season, and the hydrographic conditions found at each time are as follows:

CICLOS I . Patterns of sea surface temperature distribution in the area are presented in figure $2 a$ and in the NOAA-9 satellite image (figure $2 b$ ). The isotherms, which run parallel to the west coastline, reveal a crossshelf gradient of $5{ }^{\circ} \mathrm{C}$ and the presence of the coldest waters near the shore and south of the capes. In the Cape

\section{$\operatorname{SST}\left({ }^{\circ} \mathrm{C}\right)$}

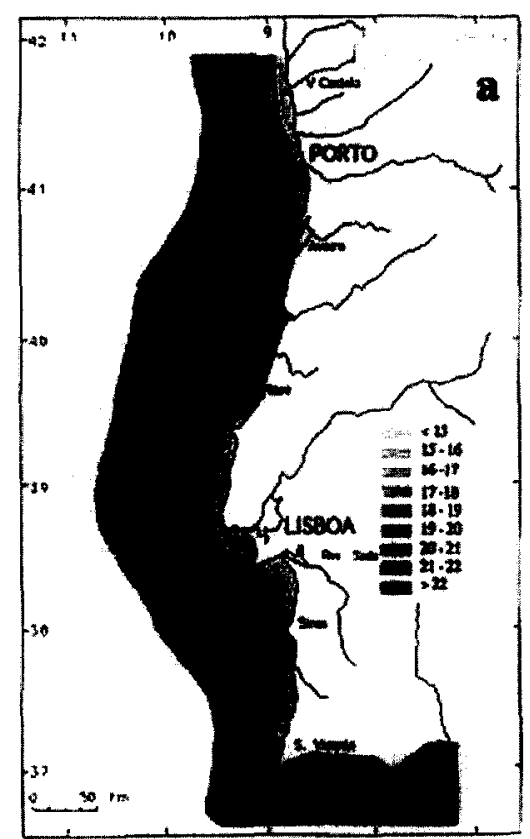

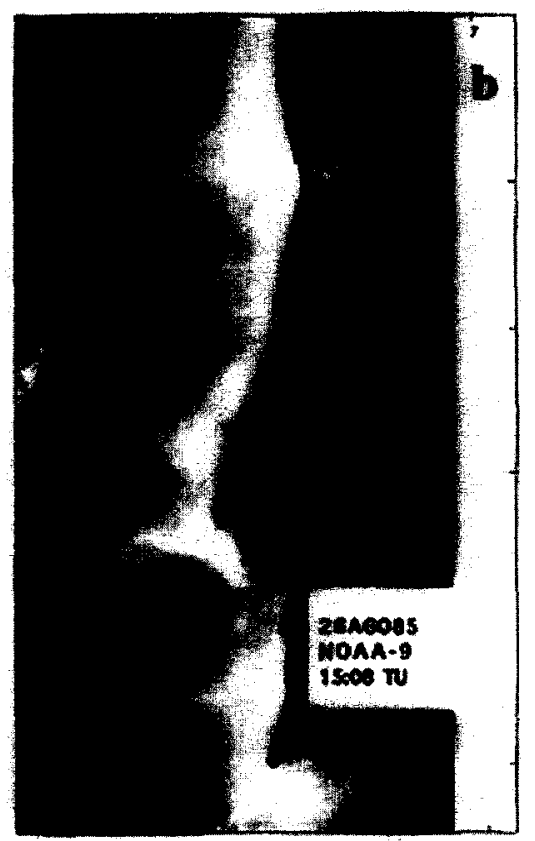

Chl-a $\left(\mathrm{mg} / \mathrm{m}^{3}\right)$

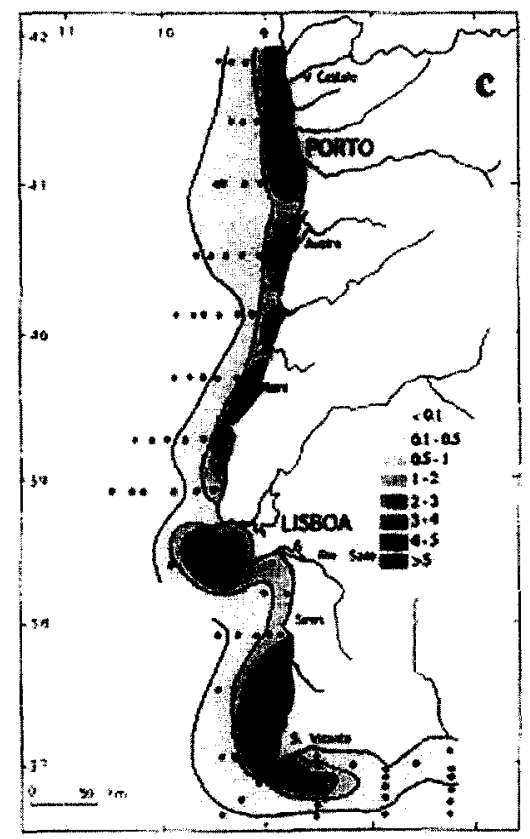

Figure 2. a- Sea surface temperature $\left({ }^{\circ} \mathrm{C}\right)$ CICLOS I - August 1985; b- Tiros- $\mathrm{N}$ thermal infrared image obtained during the summcr of 1985 (26 August 1985). (Courtesy of A. Fiuza, Institute of Oceanography - University of Lisbon); c- Chlorophyll-a surface distribution (mg $\mathrm{m}^{-3}$ ) CICLOS I - August 1985. 
$\mathrm{SST}\left({ }^{\circ} \mathrm{C}\right)$

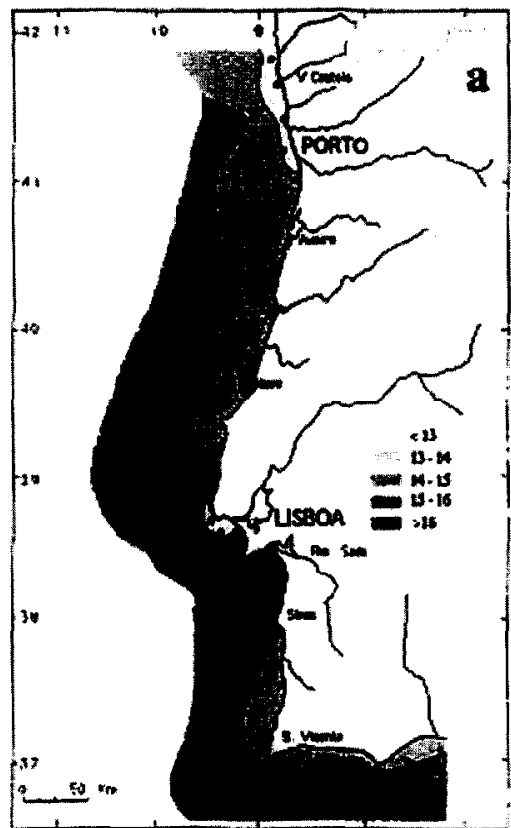

SALINITY

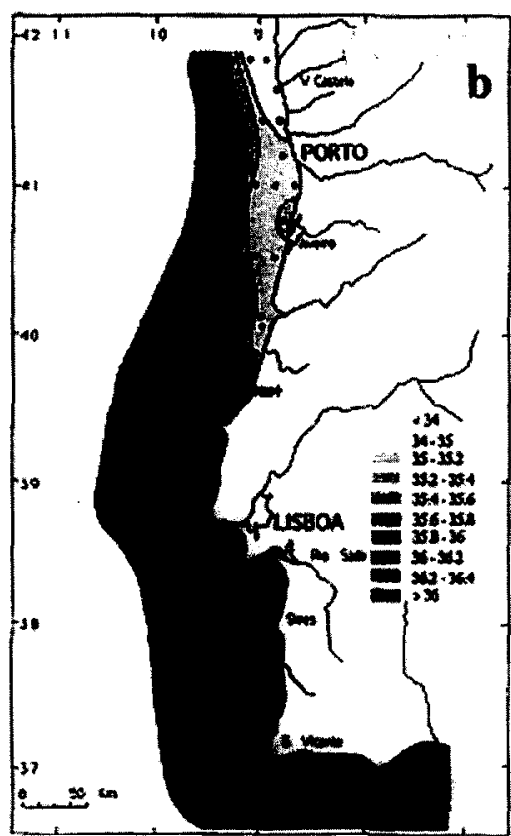

Chl-a $\left(\mathrm{mg} / \mathrm{m}^{3}\right)$

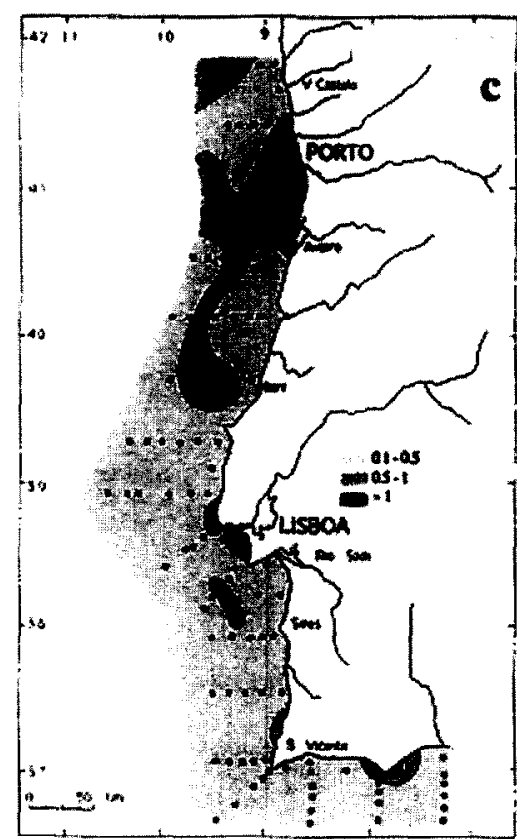

Figure 3. a- Sea surface temperature $\left({ }^{\circ} \mathrm{C}\right)$ CICLOS III - January 1986. b- Salinity distribution CICLOS III - January 1986 . c- Chlorophyll $a$ surface distribution $\left(\mathrm{mg} \cdot \mathrm{m}^{-3}\right.$ ) CICLOS III - January 1986.

S. Vincent area, the upwelling waters turn anticlockwise around the cape flowing eastward, following the pattern described by Fiúza [9]. North of the Nazaré canyon, the shelf was occupied by a shallow lens of reduced salinity water limited below by the seasonal pycnocline (figures $4,5,8$ in [17]). The innermost 10 to $30 \mathrm{~km}$ are characterized by an uplifting of the upper $40 \mathrm{~m}$ isotherms and isopycnals, sometimes reaching the surface (figure 5, F. Foz in [17]). Along the southwestern coast, and specially at Cape $S$. Vincent, upwelling was particularly intense, with waters from 50 to $120 \mathrm{~m}$ rising to the surface (figure 6, Sagres in [17]), a situation which has also been observed even during moderate upwelling events (F. Sousa, pers. comm.).

CICLOS III . During the winter cruise, sea surface temperature distribution shows a one degree gradient between coastal and offshore waters all along the northwestern coast (figure $3 a$ ). Adjacent to the southwestern and Algarve coasts, SST distribution shows a zonal distribution of isotherms with a $2.5^{\circ} \mathrm{C}$ gradient between inshore and offshore stations, a gradient also present in the salinity distribution. The existence of this colder water band is, however, not due to coastal upwelling (figure 3 b). According to Fiúza [10] this is a general fea- ture, which develops in these shallow coastal waters at the end of fall, when the whole water column begins to cool as a result of net heat loss from the surface; an idea corroborated by the presence of waters of subtropical origin $(\sigma \mathrm{t}<27.0)$ in the upper $200 \mathrm{~m}$ along most of the coast. An exception to this water column homogeneity was observed to the north of the Nazare canyon where surface stratification probably caused by river runoff was detected in the upper $50 \mathrm{~m}$ (figure $3 b$ ).

\section{RESULTS}

\subsection{Phytoplankton biomass}

During the summer, phytoplankton biomass in the upper $100 \mathrm{~m}$, measured as chlorophyll $a(\mathrm{chl} a$ ) concentration, is distributed according to the patterns of sea surface temperature, with the coldest upwelled waters near the coast being phytoplankton enriched (figure $2 c$ ). During winter, chl $a$ is low and constant along the entire coast, ranging between 0.1 and $1 \mathrm{mg} \cdot \mathrm{m}^{-3}$ (figure $3 \mathrm{c}$ ). Summer values, near the coast, are ten times higher than observed during the winter, reaching $5 \mathrm{mg} \cdot \mathrm{m}^{-3}$ north of Porto and 
UPWELLING

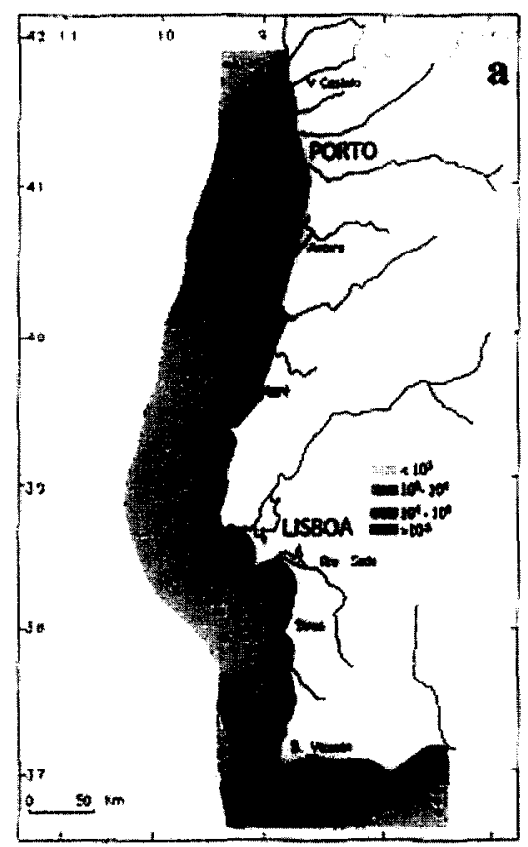

NON-UPWELLING

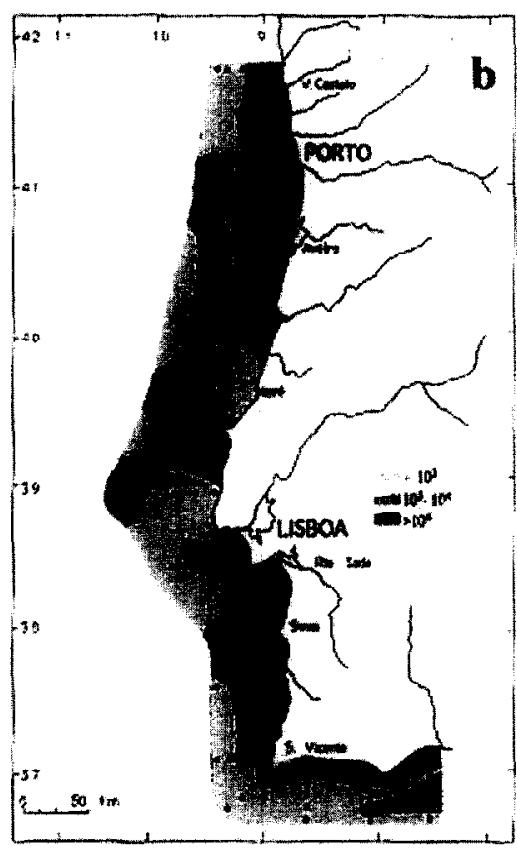

SEDIMENTS

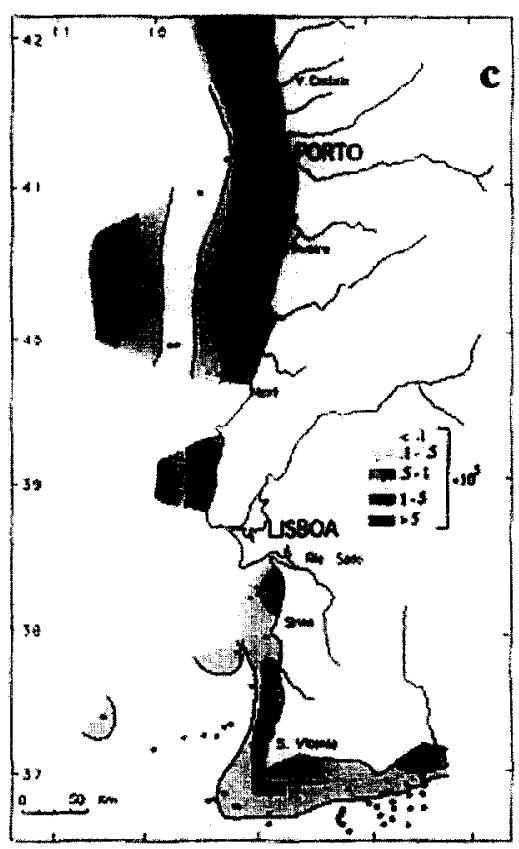

Figure 4. Distribution of the water column averaged abundance of diatoms (log cells/L); a- CICLOS I - August 1985; b- CICLOS III January $1986 ; c$ - Distribution of the diatom abundance in the sediments (number valves/cc of fresh sediment).

$3 \mathrm{mg} \mathrm{m}^{3}$ at Cape $\mathrm{S}$. Vincent. Offshore waters do not show a significant difference between the two seasons.

\subsection{Diatoms}

\subsubsection{Water Column}

The distribution of diatoms during the summer cruise follows the patterns of sea surface temperature and chl $a$ being important contributors to the general productivity caused by the occurrence of coastal upwelling (figures $2 a, c$, and $4 a$ ). Water column abundances nearshore varied between $7 \times 10^{5}$ cells/L off Porto to $2 \times 10^{5}$ cells/L off Cape S. Vicente, in the range observed in other upwelling areas $[6,8,15]$. Offshore, the abundance of diatoms is similar in both seasons, ranging from 30 to $3 \times 10^{3}$ cells $/ \mathrm{L}$. Two distinct maxima are however detected north of the Nazare Canyon during the winter cruise. One of the maxima, $4 \times 10^{4}$ cells $/ \mathrm{L}$ occurs nearshore between surface salinities of 34 and 35 , while the second maximum $\left(2 \times 10^{4}\right.$ cells $\left./ \mathrm{L}\right)$ appears towards offshore, bordering the front of haline origin (figures $4 b, 3 b$ ).

Figures $5 a$ and $b$ represent the relative abundance of diatoms within the total phytoplakton community during the two sampled seasons, summer and winter respectively. From the observation of these figures, the indications given by the total abundance are confirmed with diatoms appearing as the major contributor to the summer phytoplankton community at the temperature defined upwelling centres; that is, in the inshore area north of Nazaré and around Cape S. Vicente. The poor contribution of this group to the winter phytoplankton is also clearly illustrated.

The diatom genera which dominate the water column during the summer period, showing maxima at the upwelling centres are Pseudo-nitzschia $\mathrm{H}$. Peragallo and Chaetoceros Ehrenberg ( $10^{5}$ cells/L) (figure 11 in [17]; Appendix $1 a$ and figure 6a). Thalassiosira Cleve and Thalassionema nitzschioides (Grunow) Hustedt follow the major taxa distribution pattern, but have abundances one order of magnitude lower $\left(10^{4}\right.$ cells/L) (figures $6 d$. $g$ ). In winter, when total diatom abundances are three orders of magnitude lower, Pseudo-nitzschia and Chaetoceros abundances decrease by three and two orders of magnitude respectively, while Thalassiosira and Thalassionema nitzschioides appear as the dominant forms maintaining the summer abundances $\left(10^{4}\right.$ and $10^{3} \mathrm{cells} / \mathrm{L}$ respectively) (Appendix $1 b$, figures $6 b, e, h$ ). However, 
UPWELLING

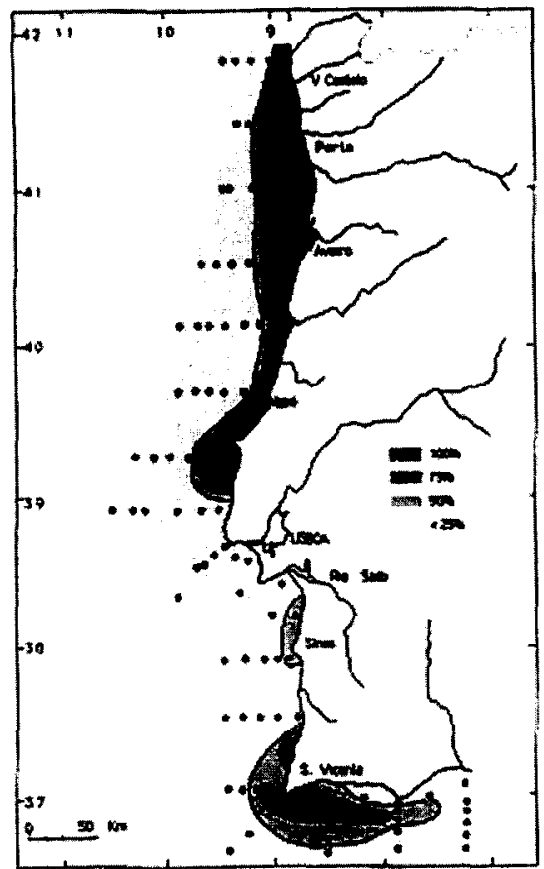

NON-UPWELLING

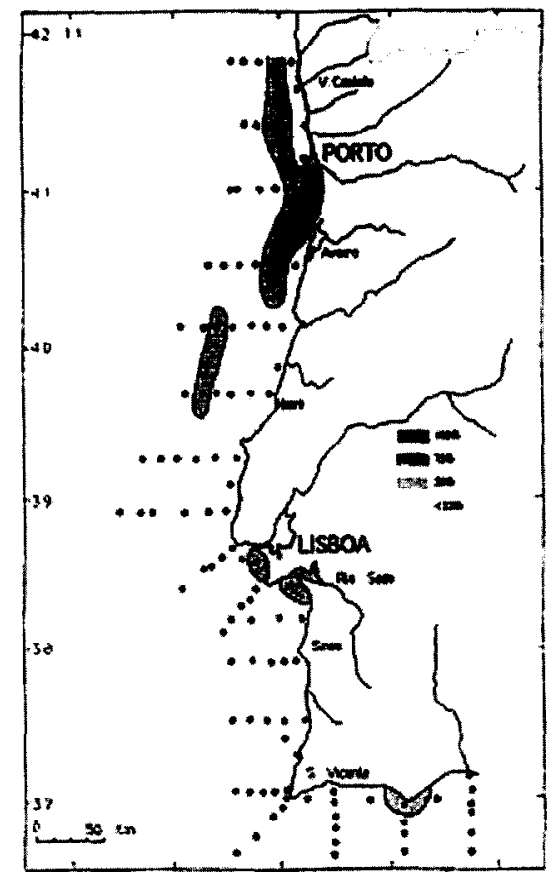

Figure 5. Distribution of the water column relative abundance of diatoms (\% of total phytoplankton community); a- CICLOS I - August 1985; b- CICLOS III - January 1986.

these two taxa show quite different distribution patterns, while Thalassionema nitzschioides is homogeneously distributed all along the shelf, Thalassiosira is clearly more abundant north of Nazaré (figures $6 h, e$ ).

\subsubsection{Sediments}

The distribution pattern of diatom abundance (number/ c.c) in the sediment samples of the Portuguese margin (Appendix 1c; figure 4c) shows generalised high abundance of diatoms on the northern part of the shelf $\left(5 \times 10^{6}\right.$ valves/c.c.) and a band of high values $\left(10^{6}\right.$ valves/c.c.) that runs parallel to the southern coast and extends along the Algarve coast, immediately to the east of Cape S. Vicente.

In the sediments, the diatom taxa which appear as dominant are Chaetoceros resting spores and Thalassiosira spp. (figures $6 c, f$ ). Also present in lower abundance, but with a more homogenous distribution along the shelf, are Thalassionema nitzschioides and Paralia sulcata (Ehr.) Cleve (figures $6 i, l$ ).

\subsection{Coccolithophorids}

\subsubsection{Water Column}

Coccolithophorids are widely distributed, but more abundant to the south of the Nazare canyon in both summer and winter sampling periods (figures $7 a, b$ ). During summer, the highest concentrations, more than $3 \times 10^{4}$ cells/ $\mathrm{L}$, are associated with upwelling and occur at Cape S. Vincent. North of Nazaré, this group is mainly distributed at mid and outershelf, with the lowest numbers $(<10$ cells/L) observed at the innershelf stations. In winter, concentrations of the same order of magnitude of the summer maxima $\left(10^{4}\right.$ cells $\left./ \mathrm{L}\right)$ are only present in some minor dispersed patches, on the southwestern and southern coasts.

If, instead of the total abundance of cells, the relative importance of coccolithophorids in the phytoplankton community $[\%$ Coccolithophorids $=$ (number cells of coccolithophorids/l) / (total number of phytoplankton cells / L)] is considered (figure $8 a, b$ ), we find that during the 
UPWELLING
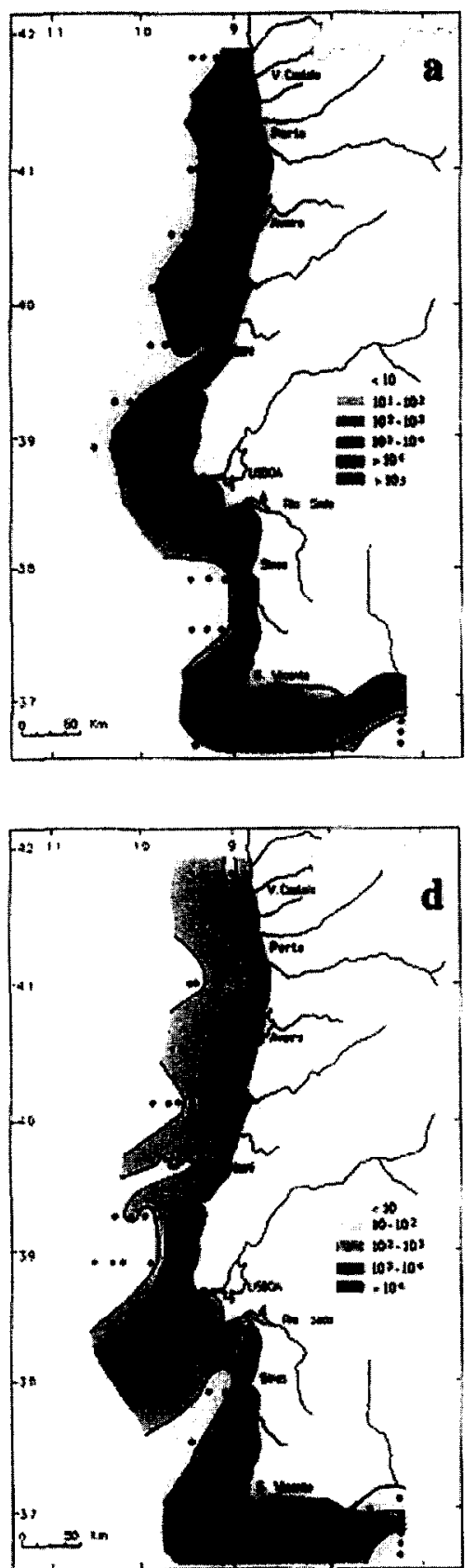

NON-UPWELLING Chaetoceros

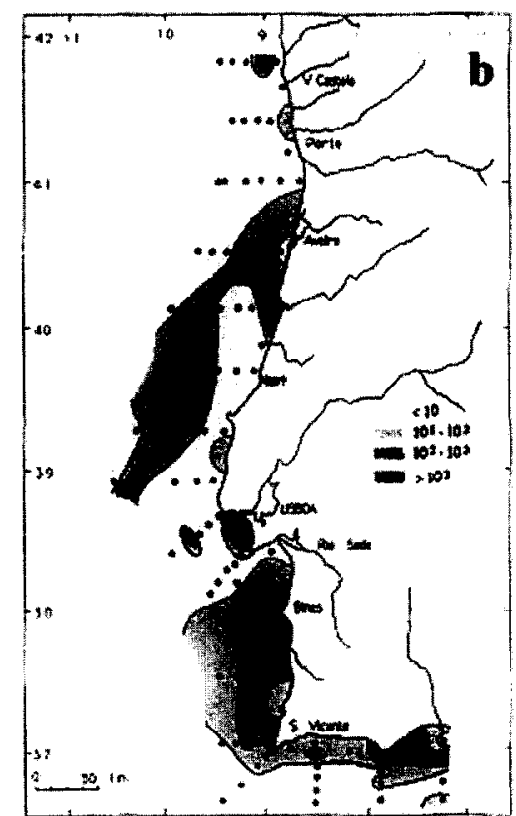

Thalassiosira

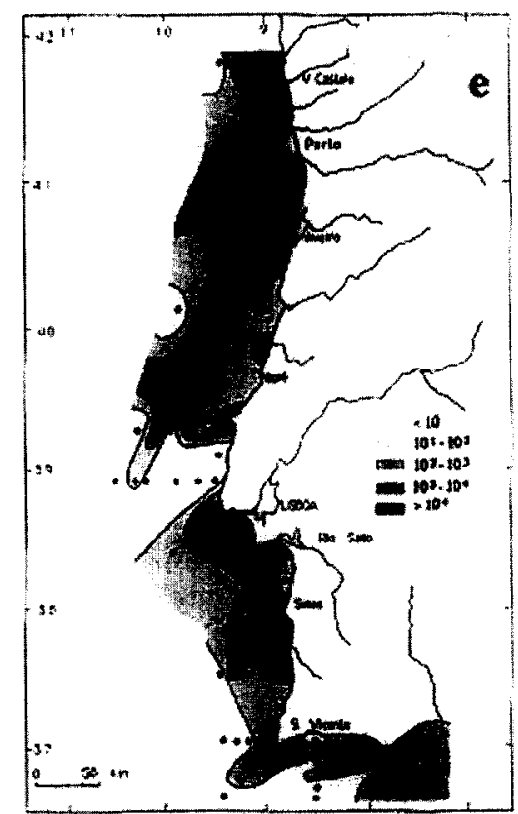

SEDIMENTS
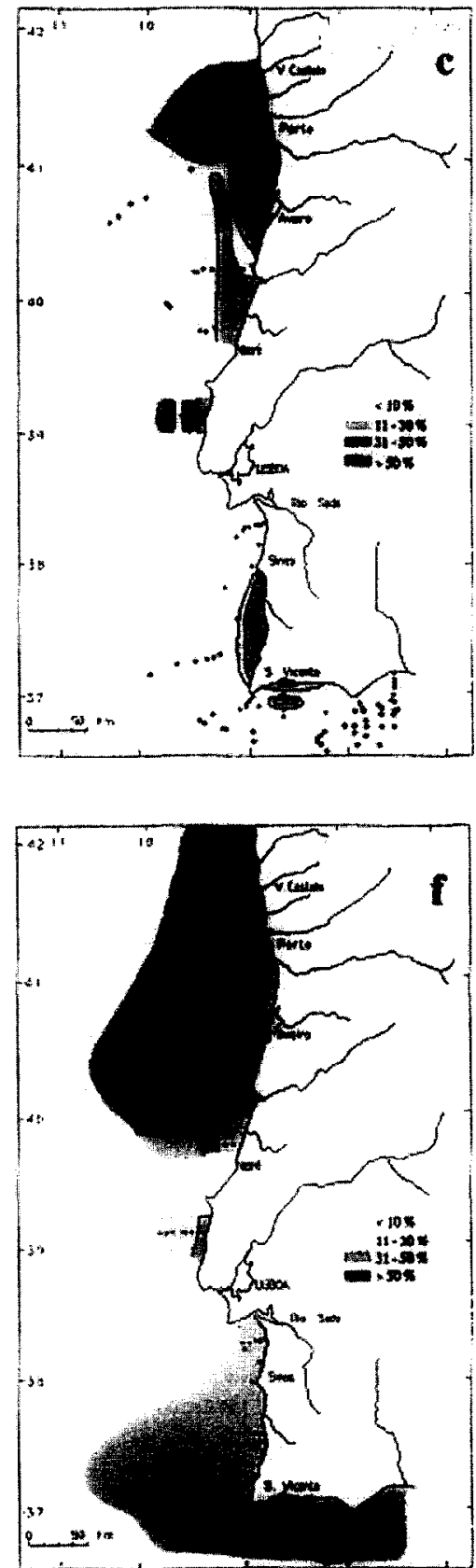

Figure 6. Distribution of the water column abundance (log cells/L) of Chaetoceros.

a- CICLOS I - August 1985; b- CICLOS III - January 1986; c- Distribution of the percent abundance in the sediments.

Distribution of the water column abundance $(\log$ cells/L) of Thalassiosira.

d- CICLOS I - August 1985; e- CICLOS III - January 1986; f-Distribution of the percent abundance in the sediments. 
UPWELLING
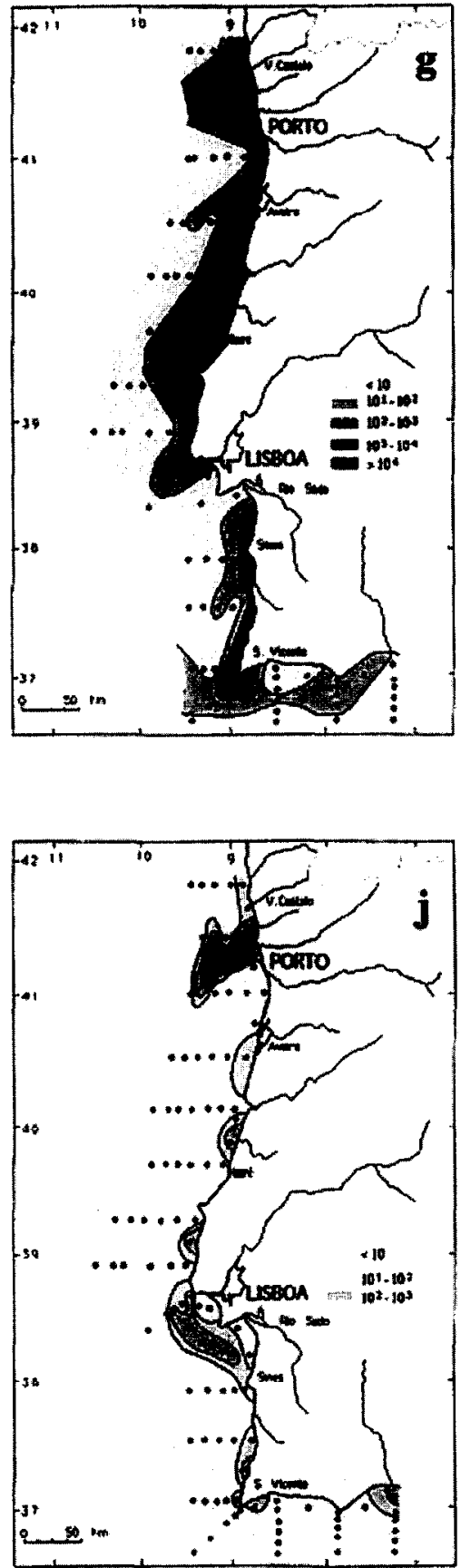

NON-UPWELLING

Thalassionema nitzschioides
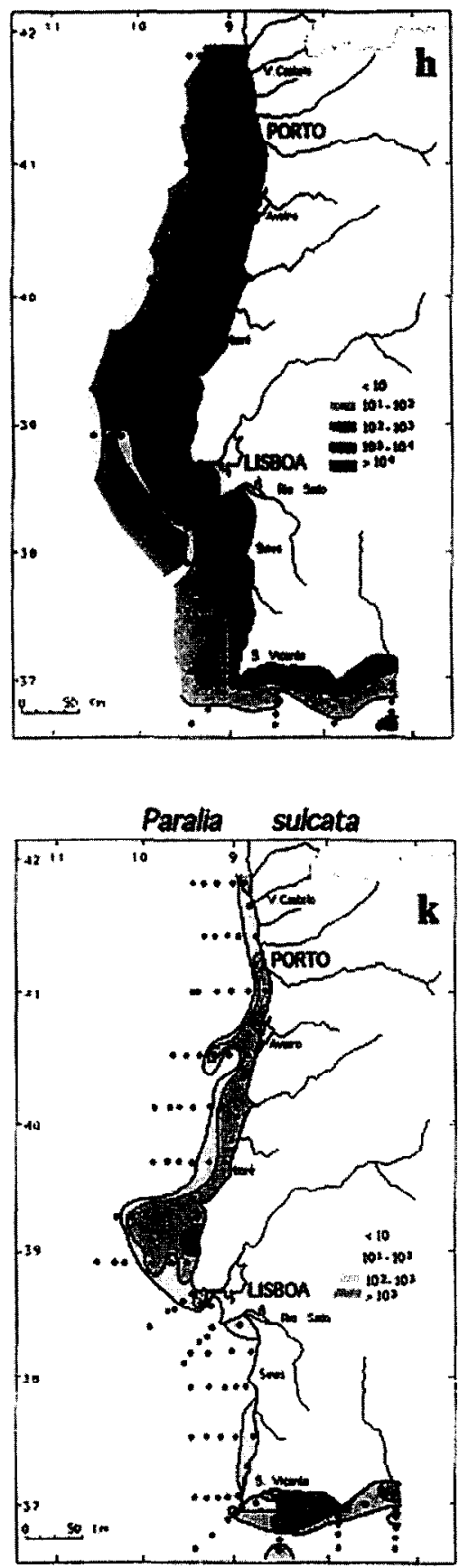

SEDIMENTS

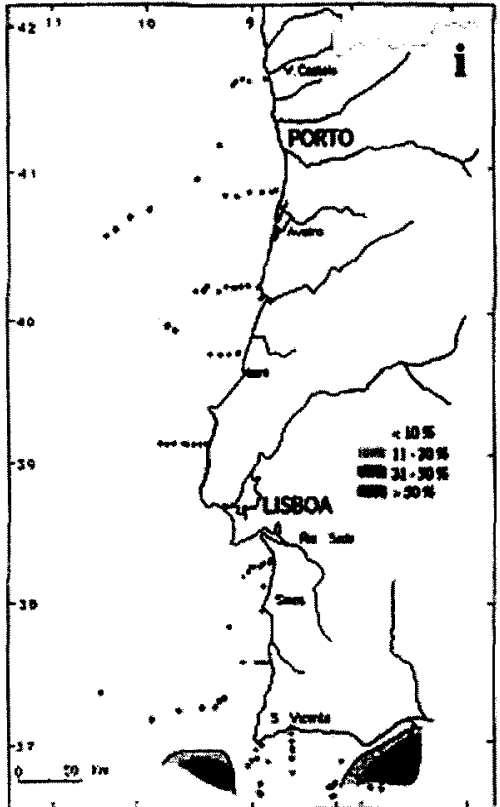

Figure 6 (continued). Distribution of the water column abundance (log cells/L) of Thalassionema nitzschioides. g- CICLOS I - August 1985; h- CICLOS III - January 1986; i- Distribution of the percent abundance in the sediments.

Distribution of the water column abundance (log cells/L) of Paralia sulcata.

j- CICLOS I - August 1985; k- CICLOS III - January 1986; 1- Distribution of the percent abundance in the sediments. 


\section{UPWELLING}

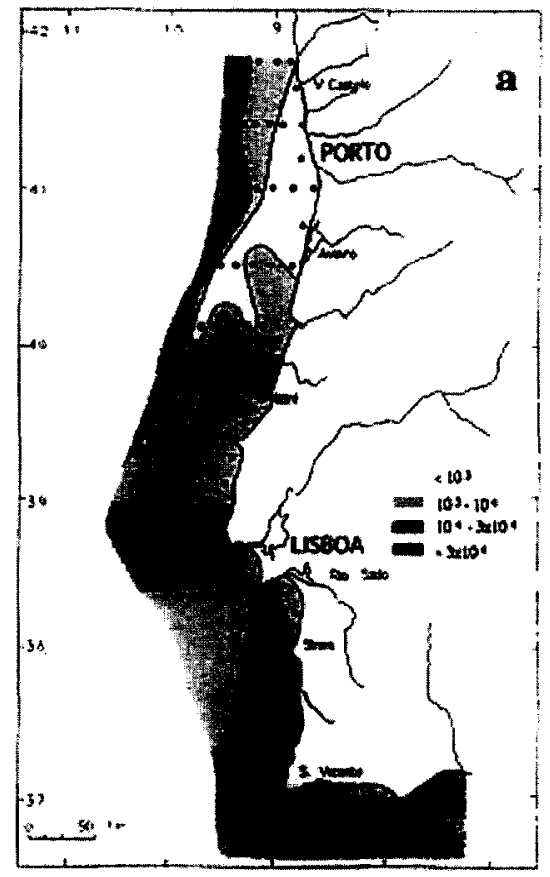

NON-UPWELLING

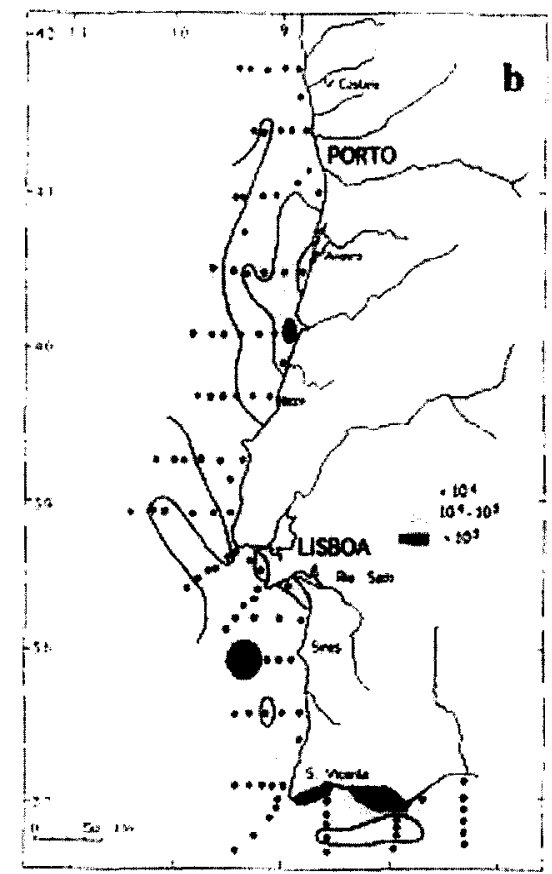

Figure 7. Distribution of the water column averaged abundance of coccolithophorids (log cells/L). a- CICLOS I - August 1985; b- CICLOS III - January 1986.

upwelling period, their importance is significantly reduced in the areas influenced by the upwelling phenomena. Higher relative abundances occur associated with warmer waters (figures $2 a$ and $8 a$ ). During the nonupwelling situation, this group composes up to $90 \%$ of the total phytoplankton community all along the south and western coasts, except for the north inshore area (Figueira da Foz to Caminha and up to the $100 \mathrm{~m}$ bathymetric), which corresponds to the area of lower salinity (figure $3 b$ ).

\subsubsection{Sediments}

Higher abundances of Coccolithophorid are found on the southwestern and Algarve coasts, while low abundances characterize the northern part of the shelf (figure $8 c$ ).

\section{DISCUSSION}

\subsection{Diatom and Coccolithophorid abundances - water column versus sediments}

If we compare the diatom abundance distribution patterns in the water column for a typical upwelling period and a non-upwelling situation (figure $4 b, a$ ) to the diatom abundances distribution in the surface sediments (figure $4 c$ ), the main observation is that the sediment distribution pattern is closely related to the water column upwelling situation, but does not show any relation to the winter water column distribution.

When the same type of comparison is made for the coccolithophorids (upwelling, non-upwelling and sediments, figure 8 ), the low abundances in the north and the highest values in the zone immediately to the north of Cape S. Vincent, observed in the sediments, reflect not only the general $\mathrm{N}-\mathrm{S}$ difference observed in the water column for both upwelling and non-upwelling situations, but also the summer water column distribution (figure $8 c$ ).

Our water column data are reduced to two discrete periods of specific seasons, not representative of the interannual variability and certainly not of the same range of scale of the sediment record. However, assuming their representativeness of the biological interseasonal variability, one can say that the diatom and coccolithophorid abundance distributions observed in the sediments is mainly a reflection of the water column distribution observed during an upwelling situation. Moreover, both 
UPWELLING

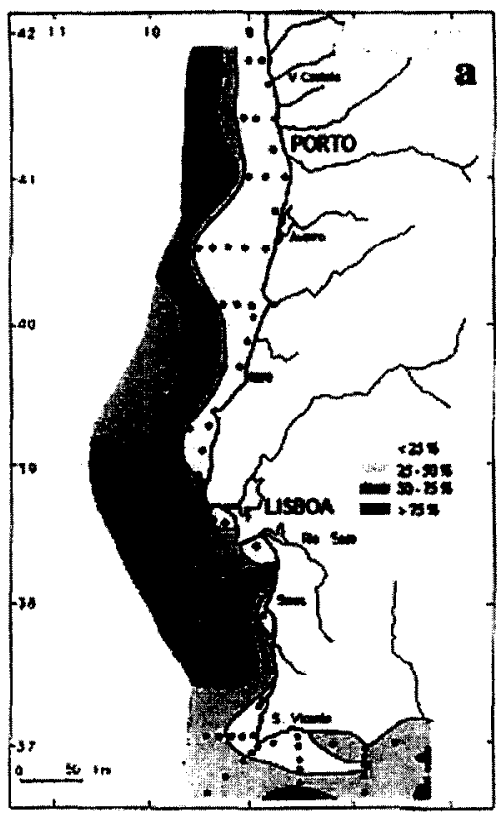

NON-UPWELLING

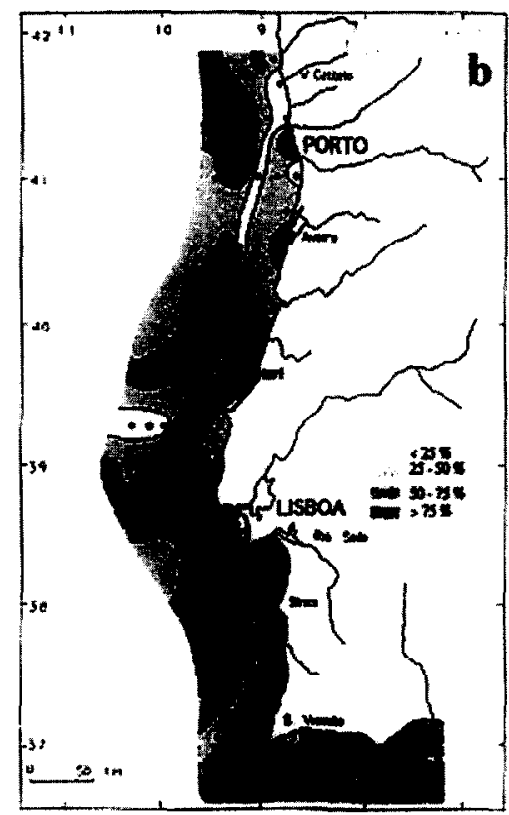

SEDIMENTS

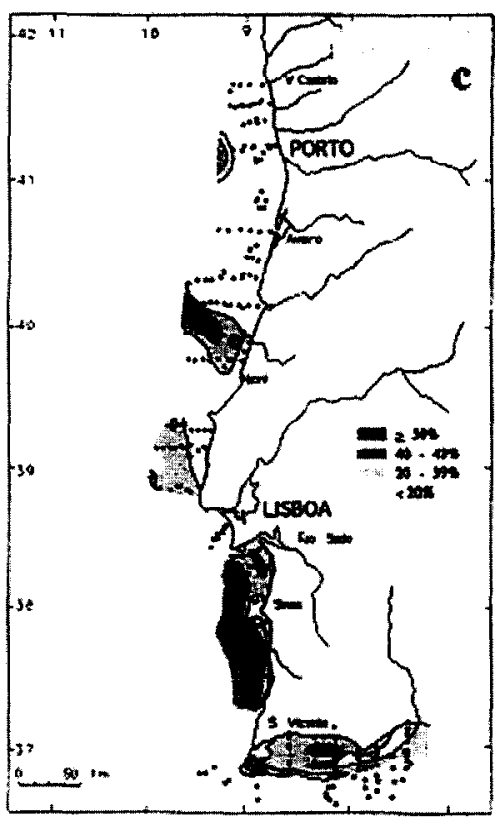

Figure 8. Distribution of the water column relative abundance of coccolithophorids (\% of total phytoplankton community). a- CICLOS I - August 1985; b- CICLOS III - January 1986; c- Distribution of the coccolithophorids abundance in the sediments (\% slide area covered by coccolithophorids).

groups' distribution patterns in the sediments preserve most of their original biological spatial variability, independently of the sediment lithology and/or the relative importance of the several geological processes known to act on the Portuguese shelf [18]. This indication, that both diatom and coccolithophorids produced during blooms are preserved with greater efficiency than those produced during non-bloom periods, has also been shown in the work of Nelson et al. [19]. Such a conclusion favours Margalef's idea which maintains that the high inputs of energy followed by a gradual decay of that same energy create discontinuity, and allow life to make history which becomes recorded in the sediments [16]. In the same way it contradicts the inference of Sancetta [23], who considers, based on the study of trap material and top box-cores material from British Columbian Fjords, that homogenisation by the geological processes, which act within the sediment mixed zone (such as bioturbation and erosion), obscures the original biological spatial variability.

Diatom abundances in the sediments of the Portuguese margin are thus confirmed as reflecting the original "proportions" of production generated by the occurrence of upwelling. Therefore, one can assume that the taxa pro- duced during this highly productive but relatively short time interval are the ones that dominate the fossil record. However, it is also well known that the sediment record is incomplete, lacking many of the diatom species present in the water column. The relatively extensive water column data, now available for this region of strong seasonal variation in productivity, appears to be an excellent opportunity to assess the relative importance of the different seasons/species to the sedimentary record, and to check the interpretations put forward by Abrantes [1].

\subsection{Diatom assemblages - water column versus sediments}

Clear differences and similarities are evident from the comparison of the most important water column taxa in both seasons and the taxa found in the sediments. The differences are the absence in the sediments of one of the most abundant summer genus, Pseudo-nitzschia, and the persistent presence in the sediments of Paralia sulcata, a species present in the plankton of both seasons but in small numbers and mainly at the more coastal stations ([17]; figure 6). The similarities are the co-occurrence and high abundances both in the water column and the 
sediments of the genus Chaetoceros and Thalassiosira, and the persistent presence of $T$. nitzschioides (figure 6).

Can we explain these differences and similarities?

The summer dominant genus Pseudo-nitzschia is a genus characteristic of the upwelling centres where primary production is maximal $[5,6,14,15,20,24]$. Pseudo-nitzschia species are, however, small and lightly silicified, and therefore very prone to dissolution and rarely preserved in the sediment record $[14,23,24]$. On the contrary, Paralia sulcata is a fairly rare species in the plankton, but often reported as important in the sediments. This dense taxon is also reported to increase in relative abundance at the deepest traps of the British Columbia Fjords [23]. This increase is attributed to lateral advection from shallower sites, which can also be invoked to explain the sedimentary record reported here, given the persistent presence of the species in the innermost part of the Portuguese shelf (figures $6 j, k$ ). Nevertheless the coastal presence of the species, a situation also recorded along the NW African coast, is known to extend its domain over the shelf during periods of strong upwelling $[5,6]$. This fact, concurrently with the inverse relationship observed in the Portuguese margin sediments between this species size and the upwelling intensity (figure $6 \mathrm{~d}$ in [1]), points to upwelling as a determining factor for its presence throughout the shelf sediments, a factor certainly enhanced by the robustness of the species.

The second most important genus in the summer water column is Chaetoceros, the genus which also dominates the sediment assemblage (figures $6 a, c$ ). The species of this genus are, like Pseudo-nitzschia, fragile forms, however the genus is characterized by its ability to form resting spores when nutrients are nearly exhausted in the euphotic zone [5, 6, 15]. According to Smith et al. [26] and Pitcher [21], diatom spores form a major component of phytoplankton settling from the upper mixed layer. The fact that Chaetoceros is one of the dominant diatoms during upwelling events, associated with its ability to form spores, may well increase its chances of becoming incorporated in the sedimentary record of coastal upwelling areas, such as Portugal, SW Africa and California $[1,24,25]$.

Thalassiosira represents another major contributor to the diatom assemblage in summer. A genus which has been reported in other upwelling zones but is also found in other areas of fertilisation and flow [5, 15]. According to Margalef [15], in an upwelling system this genus is represented by different species, with the mucilage produc- ing species related to the place and intensity of upwelling, while cells of Thalassiosira devoid of mucilage become more frequent away from the upwelling centres. Off Portugal, the genus is present in the water column with maxima of the same order of magnitude in both winter and summer conditions. Its distribution in the two seasons is, however, quite different. In summer maximum abundances occur at the upwelling centres associ ated with chl $a$ and diatoms maxima (figures $6 d, 2 c, 4 a$ ). In winter, maximum abundances occur off the Tagus and Sado estuaries and north of Nazaré, within the low salinity area clearly visible in the salinity distribution (figures $6 e, 3 b$ ). A pattern probably related to the increased fertilisation generated by the higher river runoff and nutrient input that is likely to occur in those areas $[1,10]$. Thalassiosira was, in both seasons, mainly repre sented by the species $T$. anguste-lineata (A. Schmi.) Fryxell and Hasle and T. eccentrica (Ehr.) Cleve, non mucilage producers, which together reached 60 to $100 \%$ of the total of Thalassiosira.

The distribution of Thalassiosira spp. in the sediments shows a clear N/S contrast with a higher abundance (30$50 \%$ ), especially of very small forms north of Nazaré (figure 6f). The species present are: $T$. binata Fryxell, T. decipiens (Grunow ex Van Heurck) Jorgensen, T. delicatula (Ostenfeld) Hasle and $T$. dyporocyclus Hasle, forms not identified in the biological samples, certainly due to their small size and non-existence of SEM observations. Regions of high abundance are also noticeable off the Algarve coast, where the most abundant form is T. eccentrica.

Given that the genus Thalassiosira is common in the area and represented by the same species in both seasons, neither the genus nor any of the species can be a reliable indicator of a single process. However, the similarity observed between the non-upwelling water column and sediment distribution (figures $6 e, f$ ) points to continuous (all year long) production conditions/nutrient input, as the determining factor of this genus, sedimentary record.

Another species, which is present at the same level of abundance in both sampled seasons, is Thalassionema nitzschioides. This species is a diatom common in and around upwelling centres $[12,15]$, which seems to increase in importance during periods of long and weak upwelling [5]. Off Portugal (figures $6 g, h$ ), although a secondary form during upwelling, the species is present in the upwelling centres. In winter, its level of abundance $\left(10^{3}\right.$ cells $\left./ L\right)$ is the same as during summer, and it has an homogeneous distribution all along the shelf. This 
situation seems to be reflected in the low numbers and homogeneous distribution found in the western shelf sedimentary cover.

\section{CONCLUSIONS}

Upwelling determines the production patterns observed off Portugal. At the temperature-defined upwelling centres, phytoplankton biomass at the surface is ten times higher during an upwelling situation than during a nonupwclling period. Diatoms are the major phytoplankton group during upwelling, while coccolitophorids dominate during winter.

The comparison of the total phytoplankton biomass, diatoms and coccolitophorids abundance (\# cells/L and \% abundance) distribution in the water column, during a non-upwelling and an upwelling situation, and the same groups' distribution in the sediments reveals total diatom distribution pattern in the sediments as a clear record of the diatom dominance of the phytoplankton during upwelling. The same is true for the coccolithophorids, even though it is clearly more important in winter phytoplankton. The distribution of this group in the sediments also shows a visible connection to the distribution of the same group during upwelling periods.

Water column diatom assemblages during upwelling are mainly composed of Pseudo-nitzschia and Chaetoceros followed by Thalassiosira and Thalassionema nitzschioides, while in winter Thalassiosira and Thalassionema nitzschioides are the most important taxa. In the sedi- ments, Chaetoceros dominance appears to reflect the importance of the short but high production associated with upwelling, while Thalassiosira appears to mark morc persistent fertility conditions, which are likcly to occur in the northern area.

Aside from the disparity between biological and geological scales used in this study, the recurrence of the upwelling phenomena on the Portuguese margin was shown to leave a clear imprint in the sediments, where the original hydrological and biological variability is actually preserved. Even though some plankton species, such as Pseudo-nitzschia, never make it to the sediments, this does not appear impeditive of correct paleoecological inferences from the coastal upwelling sedimentary record. In fact, the dominant taxa of each season were also shown to be dominant in the sediments, and to have distribution patterns similar to their plankton distribution.

\section{Acknowledgements}

This work was supported by JNICT ICDE contract $\mathrm{n}^{\circ}$ 572.83.92, the Instituto Geológico e Mineiro and Instituto de Investigação das Pescas e do Mar. The authors wish to thank the phytoplankton and marine geology laboratory technicians for their support with sample preparation. Thanks are also due to the masters and crews of research vessels Almeida Carvalho and Noruega for their efficient help at sea. Criticism by two anonymous reviewers contributed to improving this paper.

\section{REFERENCES}

[1] Abrantes F., Diatom assscmblages as upwelling indicators in surface sediments off Portugal, Mar. Geol. 85 (1988a) 15-39.

[2] Abrantes F., Diatom productivity peak and increased circulation during latest Quaternary deglaciation: Westem Mediterranean, Mar. Micropaleontol. 13 (1988b) 76-96.

[3] Barnola J.M., Raynaud D., Korotkevich Y.S., Lorius C., Vostok ice core provides 160,000 -year record of atmospheric $\mathrm{CO}_{2}$, Nature 329 (1987) 408-414.

[4] Berger W.H., Global Maps of Ocean Productivity, in: Productivity of the Ocean: Present and Past., Berger W.H., Smetacek V.S., Wefer G., (Eds), John Wiley and Sons, New York, 1989, 429-455.

[5] Blasco, D., Estrada M., Jones B., Short time variability of phytoplankton populations in upwelling regions - The example of
Northwest Africa, Proceedings of the International Symposium on Coastal Upwelling, Los Angeles (1981) 339-347.

[6] Blasco D., Estrada M., Jones B., Relationship between the phytoplankton distribution and composition and the hydrography in the northwest African upwelling rcgion near Cabo Corbeiro, Deep-Sea Res. 27 A (1980) 799-821.

[7] Boltovskoy D., Alder V., Abelman A., Radiolarian Sedimentary Imprint in Atlantic Equatorial Sediments: Comparison with the Early Flux at 853 m, Mar. Micropaleontol. 23 (1993) $1-12$.

[8] Estrada M., Blasco D., Two phases of the phytoplankton community in the Baja California upwelling, Limnol. Oceanogr. 24 (1979) 1065-1080. 
[9] Fiuza A., Upwelling patterns off Portugal, in: Suess E., Thiede J., (Eds.) Coastal Upwelling its sediment record, Plenum, New York, 1983, pp. 85-98.

[10] Fiuza A., Hidrologia e Dinamica das Aguas Costeiras de Portugal, Universidade de Lisboa (1984).

[11] Fiúza A., Macedo M.E., Climatological space and time variation of the Portuguese coastal upwelling, Oceanol. Acta 5 (1982) 31-40.

[12] Hasle G.R., Mendiola B.R., The Fine Structure of Some Thalassionema and Thalassiothrix Species, Phycologia 6 (1967) $107-125$

[13] Hutchings L., Pitcher G., Probyn T., Bailey G., The Chemical and Biological Consequences of Coastal Upwelling, Proceedings of the Upwelling in the Ocean. Modern Processes and Ancient Records, Berlin, 1994, 65-83.

[14] Lange C.B., Treppke U.F., Fisher G., Seasonal diatom fluxes in the Guinea Basin and their relationships to trade winds, hydrography and upwelling events, Deep-Sea Res. 41 (1994) 859-878.

[15] Margalef K., Phytoplankton communities in upwelling areas, The example of NW Africa, Oecol. Aquat. 3 (1978) 97-132.

[16] Margalef R., Asimetrías introducidas por la operación de la energía externa en secuencias de sedimentos y de poblaciones, Acta Geològica Hispànica 16 (1981) 35-38

[17] Moita T., Spatial Variability of Phytoplankton Communities in the Upwelling Region off Portugal, Proceedings of the International Council for the Exploration of the Sea, L64 (1993) 120

[18] Monteiro J.H., Dias J.A., Gaspar L., Possolo A., Recent marine sediments of the Portuguese continental shelf, Proceedings of the Present Problems of Oceanography in Portugal (1980) Lisbon.

[19] Neison D., Tréguer P., Brzezinski M., Leynaert A., Quéguiner B., Production and dissolution of biogenic silica in the ocean
Revised global estimates, comparison with regional data and relationship to biogenic sedimentation, Global Biogeochemical Cycle 9 (1995) 359-372.

[20] Olivieri E. A Description of the Hydrography and Phytoplankton Communities in the Upwelled Waters of the Cape Peninsula, South Africa, September 1972-February 1973, S. Afr. J. mar. Sci. 1 (1983) 199-229.

[21] Pitcher G., Phytoplankton seed populations of the Cape Peninsula upwelling plume, with particular reference to resting spores of Chaetoceros (Bacillariophyceae) and their role in seeding upwelling waters, Est. Coast. Shelf Sci. 31 (1990) 283-301.

[22] Rios A.F., Pérez F.F., Fraga F., Water masses in the upper and middle North Atlantic Ocean east of the Azores, Deep-Sea Res. 39 (1992) 645 658.

[23] Sancetta C., Processes controlling the accumulation of diatoms in sediments: a model derived from british Columbian Fjords, Paleoceanography 4 (1989) 235-251.

[24] Sancetta C., Diatoms in the Gulf of California: Seasonal flux patterns and the sediment record for the last 15,000 years, Paleoceanography 10 (1995) 67-84

[25] Schuette C.. Recent marine diatom taphocoenoses off Peru and off Southwest Africa. Reflection of coastal upwelling, Oregon State University (1980).

[26] Smith W., Heburn G., Barber R., O'Brien J., Regulation of phytoplankton communities by physical processes in upwelling ecosystems, J. Mar. Res. 41 (1983) 539-556.

[27] Sousa F., Bricaud A., Satellite-derived phytoplankton pigment structures in the Portuguese upwelling area, J. Geophys. Res. 97 (1992) 11,343-11,356.

[28] Wefer G., Fisher G., Seasonal Patterns of Vertical Flux in Equatorial and Coastal Upwelling Areas of the Eastern Atlantic, Deep-Sea Res. 40 (1993) 1613-1645. 
Appendix 1a. CICLOS I (August, 1985).

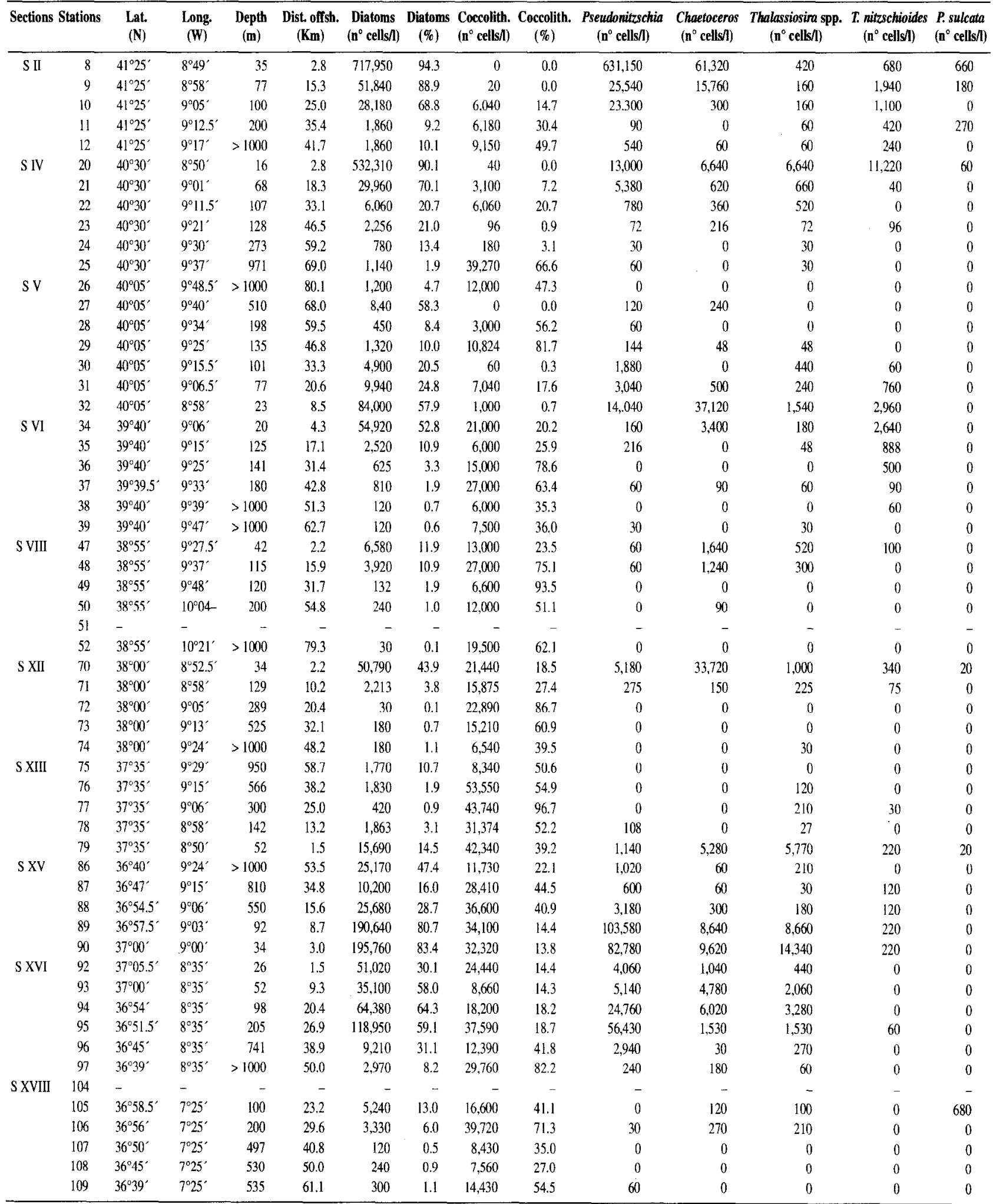


Appendix 1b. CICLOS III (January, 1986).

\begin{tabular}{|c|c|c|c|c|c|c|c|c|c|c|c|c|c|c|}
\hline Sections & Stations & $\begin{array}{l}\text { Lat. } \\
\text { (N) }\end{array}$ & $\begin{array}{l}\text { Long. } \\
\text { (W) }\end{array}$ & $\begin{array}{c}\text { Depth } \\
(\mathbf{m})\end{array}$ & $\begin{array}{l}\text { Dist. offsh. } \\
\text { (Km) }\end{array}$ & $\begin{array}{l}\text { Diatoms } \\
\left(\mathbf{n}^{\circ} \text { cells } n\right)\end{array}$ & $\begin{array}{c}\text { Diatoms } \\
(\%)\end{array}$ & $\begin{array}{l}\text { Coccolith. } \\
\left.\text { ( } \mathbf{n}^{2} \text { cells } A\right)\end{array}$ & $\begin{array}{l}\text { Coceolith. } \\
(\%)\end{array}$ & $\begin{array}{c}\text { Pseudonitzschia } \\
\left(\mathrm{n}^{\circ} \text { cells } /\right)\end{array}$ & $\begin{array}{l}\text { Chaetoceros } \\
\left(\mathrm{n}^{\circ} \text { cells } /\right)\end{array}$ & $\begin{array}{l}\text { Thalassiosira spp. } \\
\left(\mathrm{n}^{\circ} \mathrm{cell} / \mathrm{s} / \mathrm{f}\right)\end{array}$ & $\begin{array}{l}\text { T. nitzschioides } \\
\text { (n } \mathrm{n}^{\circ} \text { cellsil) }\end{array}$ & $\begin{array}{l}\text { P. sulcata } \\
\text { (n' cells })\end{array}$ \\
\hline \multirow[t]{5}{*}{ S II } & 8 & $41^{\circ} 25^{\prime}$ & $8^{\circ} 49^{\prime}$ & 33 & 2.8 & 6,170 & 18.2 & 7.120 & 21.0 & 0 & 4) & 5.660 & $8_{1 j}$ & 31 \\
\hline & 9 & $41^{\circ} 25^{\circ}$ & $8^{\circ} 58^{\circ}$ & 75 & 15.3 & 6,240 & 48.4 & 5,326 & 41.3 & 0 & 0 & $5:(00)$ & 760 & 0 \\
\hline & 10 & $41^{\circ} 25^{\prime}$ & $9^{\prime}\left(04.5^{\prime}\right.$ & 100 & 24.3 & 3.840 & 37.6 & 5,420 & 53.1 & 0 & 0 & 3.220 & 240 & (1) \\
\hline & 11 & $41^{\circ} 25^{\prime}$ & $9^{\circ} 12$ & 200 & 34.7 & $1,(150)$ & 4.4 & 16,500 & 69.1 & 300 & 0 & $|n|$ & (i) & 17 \\
\hline & 12 & $41^{\circ} 25^{\prime}$ & $9.17^{\circ}$ & 1000 & 41.7 & 540 & 6.7 & 6.750 & 83.3 & (3) & 1) & 45 & 30 & 0 \\
\hline \multirow[t]{6}{*}{ SIV } & 20 & $40^{\circ} 30^{\prime}$ & $8^{\circ} 50^{\prime}$ & 22 & 2.8 & 980 & 11.7 & $5,(40)$ & 60.1 & 0 & 0 & 180 & 120 & $54 !$ \\
\hline & 21 & $40^{\circ} 30^{\prime}$ & $9^{\circ} 01^{\prime}$ & 61 & 18.3 & 42,800 & 73.00 & 15.020 & 25.6 & 100 & $260)$ & 37,760 & 0 & 0 \\
\hline & 22 & $40^{\circ} 30^{\prime}$ & $9^{\prime \prime} 11.5^{\prime}$ & 100 & 33.1 & 4,660 & 17.9 & 5.060 & 19.4 & 60 & 40 & 2.6416 & 1,220 & 300 \\
\hline & 23 & $40^{\circ} 30^{\prime}$ & $9^{\circ} 21^{\prime}$ & 126 & 46.5 & 336 & 2.4 & 12.900 & 85.0 & 0 & 0 & 14 & 48 & () \\
\hline & 24 & $40^{\circ} 29.8^{\prime}$ & $9^{\circ} 29.7^{\circ}$ & 195 & 58.8 & 1,890 & 11.7 & 2.016 & 14.1 & $90 !$ & 0 & () & 780 & (1) \\
\hline & 25 & $40^{\circ} 30^{\prime}$ & $9^{\circ} 37^{\circ}$ & 1000 & 69.0 & 300 & 1.1 & 9.900 & 37.8 & 0 & 0 & 9) & 120 & 0 \\
\hline \multirow[t]{7}{*}{ SV } & 26 & $40^{\circ} 05^{\prime}$ & $9^{\circ} 48.6^{\circ}$ & 1000 & 80.2 & 420 & 0.5 & 21,090 & 26.1 & 150 & () & () & 0 & 0 \\
\hline & 27 & $40^{\circ} 05^{\circ}$ & $9^{\circ} 40^{\circ}$ & 470 & 68.0 & 705 & 5.2 & 12.480 & 92.3 & 0 & 150 & 120) & 180) & 0 \\
\hline & 28 & $40^{\circ} 05^{\prime}$ & $9^{3} 34.5^{\prime}$ & 200 & 60.3 & 17,790 & 36.4 & 26.100 & 53.4 & 150 & 1.350 & 12.780 & 570 & 0 \\
\hline & 29 & $40^{\circ} 05^{\circ}$ & $9^{\circ} 25^{\prime}$ & 132 & 46.8 & 432 & 4.0 & 9,600 & 89.9 & (1) & 0 & 216 & 48 & (1) \\
\hline & 30 & $40^{\circ} 05^{\prime}$ & $9^{\circ} 15.5^{\prime}$ & 104 & 33.3 & 620 & 8.5 & 6.120 & 84.3 & 0 & 0 & 141 & $261)$ & 0 \\
\hline & 31 & $40^{\circ} 05^{\prime}$ & $9^{\circ} 06.5^{\prime}$ & 75 & 20.6 & 1,300 & 12.3 & 0,120 & 86.5 & 0 & (1) & 20 & 360 & 460 \\
\hline & 32 & $40^{\circ} 05^{\prime}$ & $8^{\circ} 58^{\circ}$ & 28 & 8.5 & 17,920 & 17.4 & 36,640 & 35.6 & 240 & 7,280 & $8 i j$ & 4.640 & 1040 \\
\hline \multirow[t]{6}{*}{ S VI } & 34 & $39^{\circ} 40^{\circ}$ & $9^{\circ} 06^{\circ}$ & 32 & 4.3 & 470 & 7.0 & 6,120 & 89.7 & (1) & 0 & 30) & 100 & 210 \\
\hline & 35 & $39^{\circ} 40^{\prime}$ & $9^{\circ} 15^{\prime}$ & 123 & 17.1 & 820 & 130 & 5,140 & 813 & 320 & 0 & 0 & 40 & $41)$ \\
\hline & 36 & $39^{\circ} 40^{\prime}$ & $9^{\circ} 25^{\prime}$ & 140 & 31.4 & 575 & 1.8 & 10.200 & 32.6 & 25 & 0 & 50 & 251 & 0 \\
\hline & 37 & $39^{\circ} 40^{\circ}$ & $9^{\circ} 33^{\prime}$ & 170 & 42.8 & 7,020 & 22.6 & 19.590 & 63.0 & 6il) & 150 & 5,610 & 210 & 11 \\
\hline & 38 & $39^{\circ} 40^{\prime}$ & $9^{\circ} 38.7^{\circ}$ & 1000 & 50.9 & 17,010 & 31.6 & 22,770 & 42.3 & 150 & 30 & 15,500 & 990 & () \\
\hline & 39 & $39^{\circ} 40^{\prime}$ & $9^{\circ} 47^{\prime}$ & $>1000$ & 62.7 & 2,010 & 9.5 & 13,470 & 63.9 & 180 & 60 & 210 & 360 & ) \\
\hline \multirow[t]{6}{*}{ S VIII } & 47 & $38^{\circ} 55^{\prime}$ & $9^{\circ} 27.5$ & 36 & 2.2 & 620 & 4.1 & 9.1560 & 59.8 & () & 0 & 0 & (20) & 240 \\
\hline & 48 & $38^{\circ} 55^{\prime}$ & $9^{\circ} 37^{\circ}$ & 117 & 15.9 & 220 & 1.7 & 4,400 & 34.4 & $1)$ & 0 & 0 & 44 & 88 \\
\hline & 49 & $38^{\circ} 55^{\circ}$ & $9^{\circ} 48^{\circ}$ & 131 & 31.7 & 420 & 5.3 & 7,160 & 90.2 & 1) & 0 & 0 & $80)$ & $200)$ \\
\hline & 50 & $38^{\circ} 55^{\prime}$ & 1004 & 190 & 54.8 & 210 & 1. & 10.450 & 94.8 & 0 & () & () & () & 0 \\
\hline & 51 & $38^{\circ} 55^{\prime}$ & $10^{\circ} 21^{\prime}$ & 527 & 63.4 & 3,360 & 11.7 & $13,891)$ & 48.4 & 60 & 3,000 & 30 & 60) & 0 \\
\hline & 52 & $38^{\circ} 55^{\prime}$ & $10^{\circ} 21^{\prime}$ & 1000 & 79.3 & 1,020 & 9.7 & 7.710 & 73,0 & 94 & () & 0 & 150 & 0 \\
\hline \multirow[t]{5}{*}{ S XII } & 70 & $37^{\circ} 56^{\circ}$ & $8^{\circ} 54.5^{\prime}$ & 75 & 9.5 & 3,100 & 17.1 & 13,500 & 74.7 & 160 & 380 & 140 & 460 & 0 \\
\hline & 71 & $37^{\circ} 56^{\circ}$ & $9^{\circ} 00^{\prime}$ & 135 & 17.5 & 3,050 & 11.7 & 21,300 & 81.8 & 0 & 600 & 150 & 300 & 0 \\
\hline & 72 & $37^{\circ} 56^{\circ}$ & 907 & 290 & 27.8 & 3,810 & 7.8 & 23.130 & 47.2 & 0 & 660 & 60) & 330 & a \\
\hline & 73 & $37^{\circ} 56^{\circ}$ & $9^{\circ} 16^{\prime}$ & 545 & 40.9 & 10,350 & 14.2 & 46.770 & 64.1 & 0 & 2,880 & 450 & 540) & (3) \\
\hline & 74 & $37^{\circ} 56^{\prime}$ & $9^{\circ} 26^{\prime}$ & 1000 & 55.5 & 1.920 & 5.2 & 32.880 & 89.5 & 60) & 90 & 120 & 0 & 0 \\
\hline \multirow[t]{5}{*}{ S XIII } & 75 & $37^{\circ} 34^{\circ}$ & $9^{\circ} 25^{\circ}$ & 1000 & 52.9 & 510 & 2.2 & 21,330 & 94,0 & 120 & 60 & 0 & 120 & 0 \\
\hline & 76 & $37^{\prime} 34^{\prime}$ & $9^{\circ} 17^{\prime}$ & 656 & 41.1 & 1,080 & 4.4 & 22,230 & 91.1 & 0 & 120 & 210 & 60 & 0 \\
\hline & 77 & $37^{\circ} 34^{\circ}$ & $9^{\circ} 08^{\circ}$ & 342 & 27.9 & 2,610 & 18.8 & 5.160 & 37.2 & ( & 540 & 120) & 120 & 0 \\
\hline & 78 & $37^{\circ} 34^{\prime}$ & $9^{\circ} 00^{\prime}$ & 160 & 16.2 & 5,325 & 17.6 & 21,060 & 69.5 & 150 & 570 & 510 & $300)$ & 0 \\
\hline & 79 & $37^{\circ} 34^{\prime}$ & $8^{\circ} 50^{\prime}$ & 55 & 1.5 & 4,340 & 19.8 & 17,220 & 78.7 & 200 & 420 & 340 & 200 & 180 \\
\hline \multirow[t]{5}{*}{ SXV } & 86 & $36^{\circ} 40^{\circ}$ & $9^{\circ} 24^{\prime}$ & 1000 & 53.5 & $90)$ & 0.5 & 16,650 & 98.1 & 0 & 0 & 0 & 1) & 0 \\
\hline & 87 & $36^{\circ} 47.5^{\prime}$ & $9^{\circ} 15^{\prime}$ & 770 & 34.2 & 360 & 1.8 & 18,870 & 93.2 & 210 & 0 & 30 & 0 & 0 \\
\hline & 88 & $36^{\circ} 54.5^{\circ}$ & $9^{\circ} 06^{\prime}$ & 527 & 15.6 & 330 & 1.7 & 16,950 & 87.5 & 30 & 30 & 60 & 60 & 0 \\
\hline & 89 & $36^{0} 57.5^{\circ}$ & $9^{\circ} 03^{\prime}$ & 50 & 8.7 & 630 & 3.4 & 16.100 & 86.9 & 0 & 60 & 20 & 80 & 80 \\
\hline & 90 & $37^{\circ} 00^{\circ}$ & $9^{\circ} 00^{\circ}$ & 40 & 0 & 1,960 & 9.4 & 15,080 & 72.4 & 0 & 14i) & 20 & 2001 & 0 \\
\hline \multirow[t]{6}{*}{ SXVI } & 92 & $37^{\circ} 05.5^{\prime}$ & $8^{\circ} 35^{\prime}$ & 31 & 1.5 & 980 & 7.7 & 11,320 & 89.0 & 40 & 40 & 0 & 160 & 380 \\
\hline & 93 & $37^{\circ} 00^{\circ}$ & $8^{\circ} 35^{\prime}$ & 53 & 9.3 & 2,540 & 11.7 & 17,660 & 81.2 & 0 & 180 & 40 & 500 & 0 \\
\hline & 94 & $36: 54^{\prime}$ & $8^{\circ} 35^{\circ}$ & 100 & 20.4 & 700 & 3.3 & 20,100 & 95.0 & 0 & () & (1) & 1) & 180 \\
\hline & 95 & $36^{\circ} 51.5^{\circ}$ & $8^{\circ} 35^{\circ}$ & 210 & 26.9 & 540 & 2.1 & 18,600 & 73.2 & 0 & 0 & 30 & 60 & 210 \\
\hline & 96 & $36^{\circ} 45^{\prime}$ & $8^{\circ} 35^{\circ}$ & 700 & 38.9 & 140 & 1.1 & 8.460 & 67.7 & 0 & (1) & 0 & 0 & 0 \\
\hline & 97 & $36^{\circ} 39^{\circ}$ & $8: 35^{\prime}$ & 1000 & 50.0 & 570 & 2.8 & 12,870 & 62.9 & 90 & 0 & 0 & 0 & 90 \\
\hline \multirow[t]{6}{*}{ S XVIII } & 104 & $37^{\circ} 166^{\circ}$ & $725^{\prime}$ & 20 & 9.3 & 940 & 2.8 & 19,220 & 57.3 & 0 & 40 & 80 & 120 & 300 \\
\hline & 105 & $36^{\circ} 58.5^{\circ}$ & $7^{\circ 25}$ & 100 & 23.2 & 510 & 1.3 & 27,520 & 69.2 & 0 & 0 & 20 & 40 & 0 \\
\hline & 106 & $36^{\circ} 56^{\circ}$ & $7^{\circ} 25^{\circ}$ & 220 & 29.6 & 2.520 & 2.8 & 33,630 & 37.8 & 30 & 750 & 0 & 120 & 60) \\
\hline & 107 & $36^{\circ 50}$ & $7^{\circ} 25^{\circ}$ & 490 & 40.8 & 1,140 & 4.3 & 25,080 & 94.1 & 30 & 180 & 30) & 0 & 0 \\
\hline & 108 & $36^{\circ} 45^{\prime}$ & 725 & 550 & 50.0 & 1.560 & 6.7 & 20.670 & 89.0 & 510 & 0 & 30) & 0 & 0 \\
\hline & 109 & $36^{\circ} 39^{\circ}$ & $7^{\circ} 25^{\circ}$ & 528 & 61.1 & 510 & 1.9 & 25,590 & 96.9 & 30 & 90 & 30 & 90 & 0 \\
\hline
\end{tabular}


Appendix 1c. Sediments .

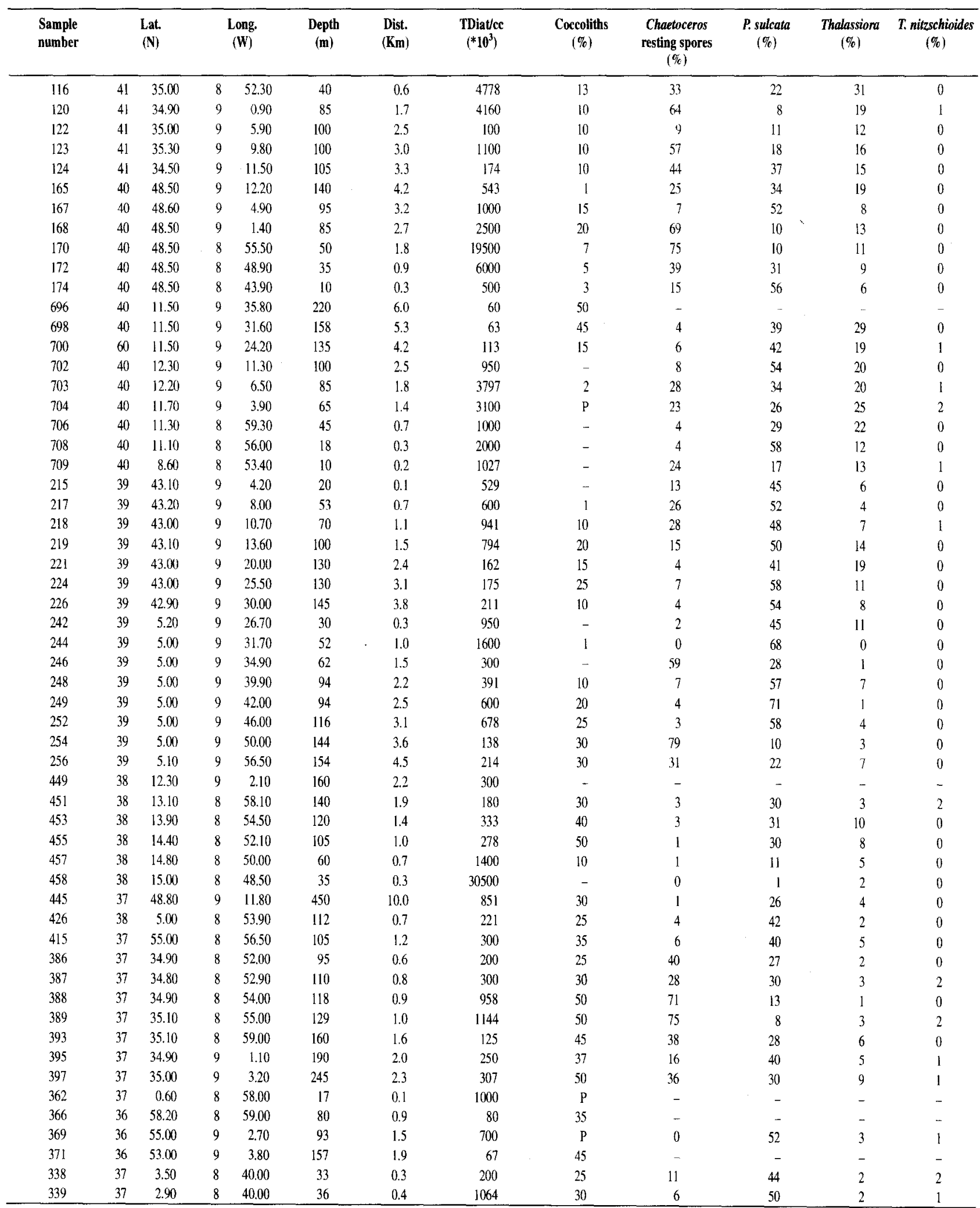


F. ABRANTES, M.T. MOITA

Appendix 1c. Sediments (continued).

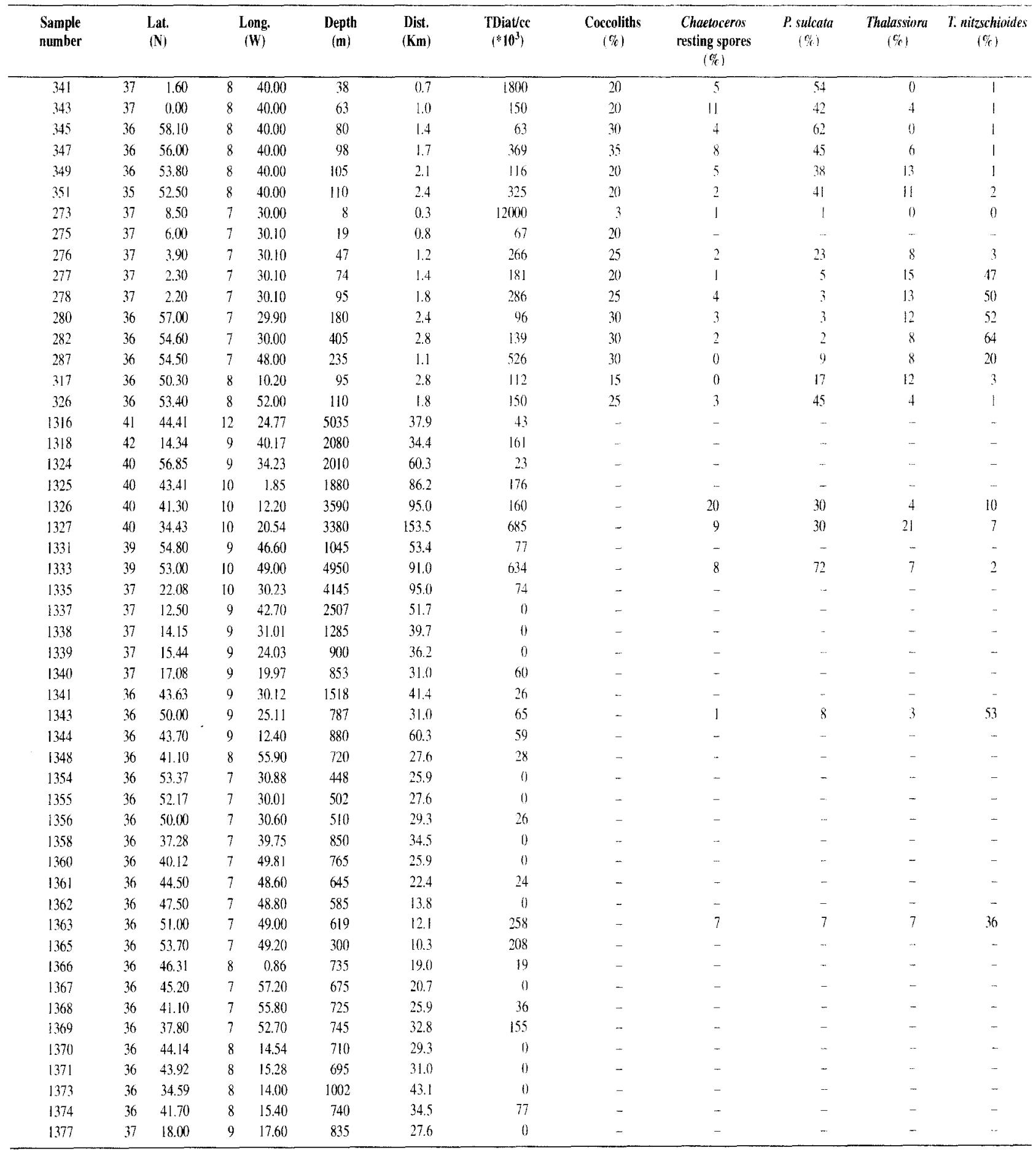

